\title{
Клінічний випадок хірургічного лікування секвестрації легені
}

\author{
A. V. DROZD, T. V. MURAVYOV, T. I. MARTSUN \\ Zhytomyr Regional Clinical Hospital by O. F. Herbachevskyi
}

\section{CLINICAL CASE OF SURGICAL TREATMENT OF LUNG SEQUESTRATION}

Секвестрація легені (СЛ) є досить рідкою вадою розвитку, зумовленою комбінованим порушенням розвитку всіх структур, що утворюють легеню, при якому ділянка легеневої тканини частково або повністю відділяється на ранніх стадіях ембріогенезу та розвивається незалежно від основної легені, являючи повністю ектоповану тканину, або розміщується всередині функціонуючої легені. СЛ має ізольовану бронхіальну систему та одну або декілька аномальних артерій, що відходять від грудного та черевного відділу аорти або її гілок (внутрішньої грудної та міжреберної). Венозний відтік здіснюється при внутрішньолегеневій секвестрації в легеневу вену або в системy vv.Azygos et Hemiazygos, а при позалегеневій у систему верхної або нижньої порожнистих вен. Сполучення між бронхами і секвестрованою ділянкою в більшості випадків відсутнє.

Більшість авторів, описуючи цю ваду ровитку, виділяє внутрішньочасткову та позалегеневу форми легеневої секвестрації. В першому випадку секвестрована легенева тканина міститься в нормальній легеневій тканині, тоді як позалегенева секвестрація може розміщуватися як у середині легеневої тканини, так і за її межами. За даними літератури, внутрішньолегенева секвестрація зустрічається в шість разів частіше, ніж позалегенева.

Вперше цю ваду описав C. Rokitansky в 1856 р., повідомив про випадок кістозно зміненої додаткової частки розміщеної в паренхімі нормально розвинутої легені. Рryсе (1946р.) ввів у практику термін “секвестрація”.

ЛС може поєднуватися 3 іншими вадами та аномаліями розвитку легеневої, бронхіальної та судинної системи.

Внутрішньочасткова секвестрація зазвичай локалізується в нижніх частках легень, зліва дещо частіше, ніж справа. Більш ніж у 80 \% випадків зміни виявляються в задньо-базальних сегментах і лише в 6 \% - в апікальному. Верхньо- і середньочасткова секвестрація зустрічається рідко (1-2\%).

При позачастковій секвестрації аномальна ділянка легені частіше розташовується в грудній порожнині над діафрагмою, рідше в черевній порожнині. Описані випадки розміщення позалегеневої секвестрації в порожнині перикарда, в ділянці грудної стінки та шиї. Позачастково розташовані секвеструвальні ділянки можуть зростатися із сусідніми органами (стравоходом, шлунком та ін.), іноді порушуючи їх функцію.

Описані випадки одночасної наявності внутрішньолегеневої та позалегеневої секвестрації. Частота секвестрації серед неспецифічних захворювань легень, за даними різних авторів, складає $0,8-2 \%$.

Клінічні прояви ЛС можуть бути відсутні протягом ряду років до розвитку інфекції в секвеструвальній ділянці, що перебігає з клінічною картиною пневмонії, часто рецидивуючою. На оглядових рентгенограмах у 2-х проекціях має місце інтенсивне гомогенне або негомогенне затемнення овальної, округлої або неправильної форми. В ряді випадків на фоні затемнення видно одну або множинні кістозні порожнини з рівнем рідини. Легеневий малюнок у навколишній тканині може бути або не змінений, або посилений та деформований. На бронхограмах бронхи в зоні аномалії деформовані, помірно розширені.

На сьогодні найбільш інформативним методом діагностики ЛС $є$ КТ ОГК та аортографія за Сельдінгером. Але, як правило, в дорослому віці ЛС є знахідкою при операційному втручанні.

Єдиним методом лікування СЛ є операційний.

Із 2009 до 2014 року в нашому відділенні на лікуванні перебували два пацієнти з ЛС. Перший - чоловік віком 42 роки, з внутрішньолегеневою 
секвестрацією, що локалізувалась у нижній частці лівої легені. Був оперований з приводу периферичного утвору нижньої частки лівої легені. Виконано нижню лобектомію. Остаточний діагноз був встановлений під час операційного втручання (аберантна судина розміщувалася в товщі легеневої зв'язки) та наступного патогістологічного дослідження.

Наводимо клінічний випадок 3 практики нашого відділення.

Пацієнтка П. віком 37 років, госпіталізована у відділення торакальної хірургії ЖОКЛ 14.04.14 p. зі скаргами на задишку при фізичному навантаженні, сухий кашель, періодичний субфебрилітет. 3 анамнезу: хворіє близько 10 років.

Неодноразово перебувала на стаціонарному лікуванні з приводу пневмонії, бронхіту за місцем проживання. Діагноз: секвестрація легені, був встановлений у 2011 році під час стаціонарного лікування у відділенні торакальної хірургії ОКЛ за

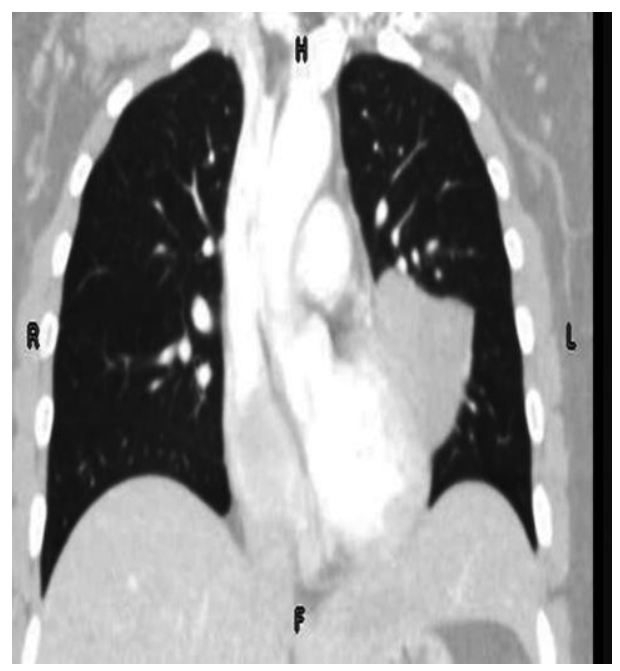

Рис. 1. Скани КТ ОГК.

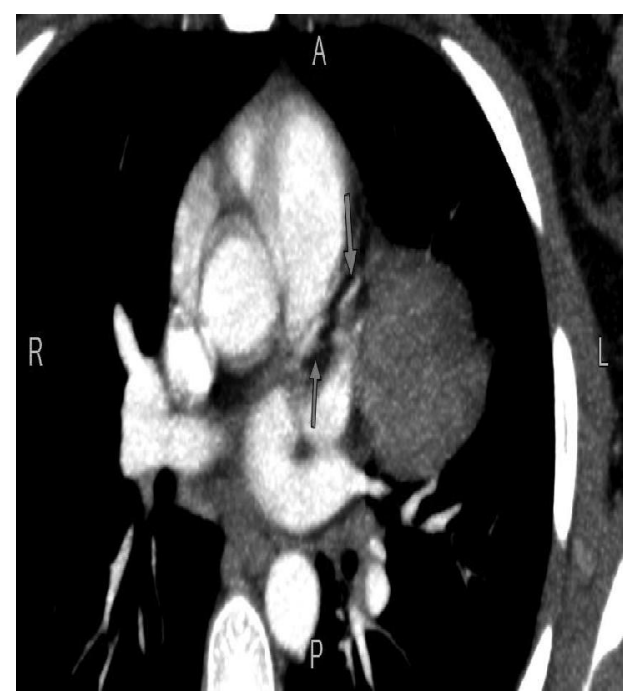

допомогою КТ ОГК з аортографією від 04.07.11 p. Від операційного лікування тоді відмовилася. Повторно госпіталізована для операційного лікування.

Стан задовільний. Дихання везикулярне. АТ 130/80 мм рт. ст. ЧСС - 86 за 1 хв. Лабораторні обстеження: ЗАК (14.04.14): Нb - 141 г/л, ер. -4,4 Т/л, КП - 0,9, лейк. - 5,6 Г/л; лейкограма: п - 4 \%, с $70 \%$, е - $1 \%$, л - $21 \%$, м - $4 \%$, ШОЕ - 5 мм/год.

УЗД ОЧП (14.04.14): хронічний холецистопанкреатит. ССД. УЗД ОГК: в обох плевральних порожнинах додаткових утворів та вільної рідини не виявлено. ЕКГ (14.04.14): ритм синусовий, нормальне положення осі серця. ЕхоКС (16.04.14): порожнини серця не збільшені. Клапанні структури без запальних змін. Скоротлива здатність міокарда збережена. ФВ - 61 \%. Кардіолог (16.04.14): міокардіодистрофія змішаного генезу. СН 0 ст. ФБС (16.04.14): ТБД без патології. СПГ (16.04.14): життєва ємність легень у нормі. Порушення трахеобронхіальної прохідності не виявлено. КТ ОГК 15.04.14 (рис. 1, 2):
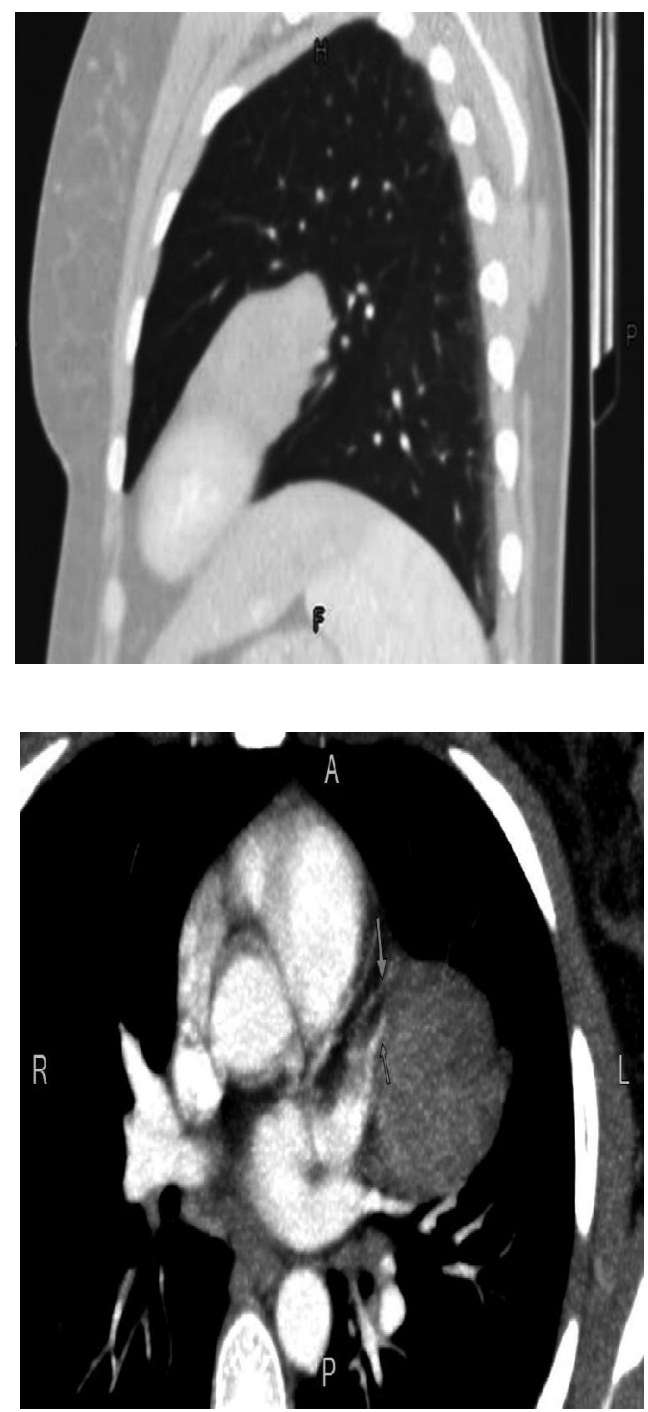

Рис. 2. Скани КТ ОГК. 
KT-ознаки найімовірніше характерні для лівобічної внутрішньолегеневої секвестрації.

Передопераційний діагноз: внутрішньолегенева секвестрація верхньої частки лівої легені. 20.04.14 р. пацієнтці в плановому порядку виконано операційне втручання в об'ємі: видалення позалегеневої секвестрації з частковою атиповою сегментарною резекцією S3 лівої легені.

Бокова торакотомія в IV м/p зліва. При ревізії плевральна порожнина вільна, між перикардом та язичковими сегментами міститься пухлиноподібний утвір, кістозної будови, неправильної форми, щільний, рожевого кольору, розміром 7x5x5 см, який ніжкою виходить із ділянки S3 та підростає до межистіння та перикарда. Утвір від'єднаний від перикарда. Медіастинотомія. Аберантна судина (діаметр до 2 мм), що живить утвір, відходить від дуги аорти, проходячи через паренхіму S3. Судина виділена, прошита, перев'язана та пересічена. За допомогою УО-60 атипова часткова сегментарна резекція S3. Іншої патології в плевральній порожнині не

\section{СПИСОК ЛІТЕРАТУРИ}

1. Вроджені вади легень: діагностика, клініка, лікування / Ладний О. Я., Кошак С. Ф., Король Ю. І. [та ін.] // Український пульмонологічний журнал. - 2003. - № 2. - С. 7072.

2. Макаров А. В. Врожденные аномалии розвития бронхолегочной системы (диагностика, хирургическое лечение) / А. В. Макаров, П. П. Сокур // Український пульмонологічний журнал. - 2003. - № 2. - С. 72-74.

3. Грудная хирургия / В. А. Картавова, Ю. Н. Левашев, Ю. Ф. Некласов [и др.]. - 1984. - № 5. - С. 31-36.

4. Королев Б. А. Аномалии и пороки развития легких / виявлено. Санаційна ФБС на операційному столі. Рана пошарово ушита. Крововтрата - 100 мл.

Перебіг післяопераційного періоду - без ускладнень. На контрольній рентгенограмі легеня розправлена. Дренажі видалено на третю добу. Післяопераційна рана загоїлася первинним натягом. Патогістологічне дослідження №16021-25 від 08.05.14: позалегенева секвестрація легені представлена ділянкою аномально розвинутої легеневої тканини 3 різної величини кістами бронхогенного типу. До секвестрованої ділянки через паренхіму незміненої легені підходить артеріальна судина великого січення.

Пацієнтка виписана в задовільному стані на 9-ту добу після операції. При контрольному огляді через 14 днів скарги на помірний біль у ділянці післяопераційної рани. Рубець без ознак запалення. Рентгенологічно: в ділянці ліній апаратного шва вогнищевих та інфільтративних тіней не виявлено. Повторний огляд через 1 рік - без скарг.

Даний випадок становить інтерес у плані діагностики та техніки операційного лікування.

Б. А. Королев, Б. Е. Шахов, А. В. Павлунин. - Н. Новгород. : НГМА, 2000.

5. Харитонов В. А. Кровоснабжение при внутридолевой секвестрации легкого / В. А. Харитонов // Грудная хирургия. - 1990. - № 3. - С. 73-74.

6. Дужий И. Д. О легочной секвестрации / И. Д. Дужий, Н. Г. Тертышный // Клиническая хирургия. - 1989. - 10. C. 35-36.

7. Sade R. M. The spectrum of pulmonary sequestration / R. M. Sade, M. Clouse, F. H. Ellis // Am. Thorac. Surg. - 1974. Vol. 18. - P. 644-658.

Отримано 06.08.15 